\title{
Credit risk and technical efficiency in Brazilian credit unions
}

\author{
LUA SYRMA ZaNIAH SANTOS ${ }^{1}$ \\ VALÉRIA GAMA FULLY BRESSAN ${ }^{2}$ \\ VILMAR RODRIGUES MOREIRA ${ }^{3}$ \\ ROMEU EUGÊNIO DE LIMA ${ }^{4}$
}

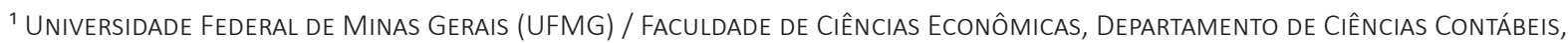
BELO HORIZONTE - MG, BRAZIL

2 Universidade Federal de Minas Gerais (UFMG) / Faculdade de CiênCIAS Econômicas, Programa de Pós-Graduação em CONTROLAdoria E CONTABILIDAde dA FACE, BELO HORIZONTE - MG, BRAZIL

3 Pontifícia Universidade Católica do Paraná (PUCPR) / Escola de Negócios, Programa de Pós-Graduação em GESTÃo de COOPERATIVAS, CURITIBA - PR, BRAZIL

${ }^{4}$ Banco Central do Brasil, Belo Horizonte - MG, Brazil

\begin{abstract}
This study analyzed the relationship between credit risk and the efficiency of Brazilian credit unions in the period from 2008 to 2017. The two-stage data envelopment analysis model was used to obtain efficiency scores, with the analysis of a Tobit model in the second stage. Specialists were consulted for the construction and validation of efficiency scores, which is a contribution of this study in relation to the others. It was found that the higher the credit risk, the lower the efficiency scores, and that credit unions that manage to maintain their continuity in the market and diversify their products had higher efficiency scores, consequently generating greater benefits to their members. Additionally, cooperatives must pay attention to the number of service points and periods of economic recession. The increase in the number of service points reduces efficiency scores. When considering the period of Brazilian economic downturn, measured from 2015 to 2017, there was a negative impact on the average efficiency scores of the cooperatives. As a limitation, it is reported that the results are derived from the inputs and outputs selected from accounting and financial information, and it is suggested that new variables related to the social dimension of cooperatives be incorporated into other studies to assess the overall efficiency of Brazilian credit unions.
\end{abstract}

Keywords: Credit unions. Efficiency. Credit risk. DEA. Tobit.

\section{Risco de crédito e eficiência técnica nas cooperativas de crédito brasileiras}

\section{Resumo}

Este estudo analisa a relação entre o risco de crédito e a eficiência das cooperativas de crédito brasileiras no período de 2008 a 2017 . Utilizou-se o modelo de Data Envelopment Analysis em dois estágios para a obtenção dos escores de eficiência, com a análise de um modelo Tobit no segundo estágio. Foram consultados especialistas para a construção e a validação dos escores de eficiência, o que é uma contribuição desse estudo em relação aos demais. Constatou-se que, quanto maior o risco de crédito, menores os escores de eficiência. De igual modo, viu-se que as cooperativas de crédito que conseguem manter sua continuidade no mercado e diversificam seus produtos tiveram maiores escores de eficiência e, por consequência, geraram mais benefícios aos associados. Adicionalmente, as cooperativas devem se atentar no número de pontos de atendimentos e em períodos de recessão econômica. O aumento do número de pontos de atendimento reduz os escores de eficiência. Considerando o período de retração econômica brasileira medido no período de 2015 a 2017, verificou-se um impacto negativo nos escores de eficiência médios das cooperativas. Como limitação, os resultados são decorrentes de inputs e outputs selecionados de informações contábeis e financeiras, de modo que se sugere que novas variáveis relacionadas à dimensão social das cooperativas sejam incorporadas em outros estudos a fim de avaliar a eficiência global das cooperativas de crédito brasileiras.

Palavras-chave: Cooperativas de crédito. Eficiência. Risco de crédito. DEA. Tobit.

\section{Riesgo de crédito y eficiencia técnica en las cooperativas de crédito brasileñas \\ Resumen}

Este estudio analizó la relación entre el riesgo crediticio y la eficiencia de las cooperativas de ahorro y crédito brasileñas en el período de 2008 a 2017. El modelo de análisis de envoltura de datos en dos etapas se utilizó para obtener puntajes de eficiencia, con el análisis de un modelo tobit en la segunda etapa. Es de destacar que se consultó a especialistas para la construcción y validación de puntajes de eficiencia, lo que constituye una contribución de este estudio en relación con los demás. Se constató que cuanto mayor era el riesgo de crédito, menores eran los puntajes de eficiencia y que las cooperativas de ahorro y crédito que lograban mantener su continuidad en el mercado y diversificar sus productos tenían puntajes de eficiencia más altos, lo que generaba mayores beneficios para sus miembros. Además, las cooperativas deben prestar atención a la cantidad de puntos de servicio y períodos de recesión económica. El aumento del número de puntos de servicio reduce los puntajes de eficiencia. Y considerando el período de recesión económica brasileña, medido de 2015 a 2017 , hubo un impacto negativo en los puntajes promedio de eficiencia de las cooperativas. Como limitación, se observó que los resultados se derivan de las entradas y salidas seleccionadas de información contable y financiera, y se sugiere incorporar nuevas variables relacionadas con la dimensión social de las cooperativas en otros estudios para evaluar la eficiencia global de las cooperativas de crédito brasileñas.

Palabras clave: Cooperativas de crédito. Eficiencia. Riesgo de crédito. DEA. Tobit. 


\section{INTRODUCTION}

Credit unions provide credit and financial services to communities that otherwise might not have access to them, especially in times of economic crisis (CREAR, 2009). However, their activities are subject to different risks. The expansion of the participation of these organizations in the National Financial System (NFS) can impact the sector's competitiveness, which could lead to greater risk taking (FIORDELISI, MARQUES-IBANEZ, and MOLYNEUX, 2011). These risks often culminate in bankruptcy, as occurred with the Lehman Brothers in the U.S., the Banco Nacional and the Banco do Comércio e da Indústria of São Paulo, Brazil, showing the high risk scenarios in which these institutions operate (MELO and LIMA, 2015).

The concern with risk situations involving financial institutions in the 1970s led to the emergence of the Basel Committee on Banking Supervision (BCBS), which instituted new parameters for regulatory capital requirements, considering the risks associated with exposures, governance and transparency of institutions (BANCO CENTRAL DO BRASIL, 2019a).

Among the risks linked to financial organizations, there are credit, liquidity, operational and market risks, so that risk management must be part of the activities of credit unions, even if such organizations are not intended to accumulation of profits, but provide services to members efficiently. In this sense, an inadequate risk management can have a decisive impact on their continuity and can lead a cooperative to dissolution (FREITAS, AMARAL and BRAGA, 2008; KAUPELYTÈ and MCKARTHY, 2006).

A potential effect of the economic crisis on the financial system is the increase in default levels and, consequently, lower operating margins. The volume of non-performing loans becomes then a proxy for measuring financial stability, due to the fact that there are high levels of default in insolvent banks (BERGER and DEYOUNG, 1997; PODPIERA and WEILL, 2008). In several investigations, defaulted credits, or even the estimates of losses with them, were used as risk proxies for financial institutions (BRANCO, SALGADO, CAVA et al., 2017; CAVA, SALGADO, BRANCO et al., 2016; HOU, WANG and ZHANG, 2014; SATHYE, 2005; TABAK, CRAVEIRO and CAJUEIRO, 2010). The financial crisis that started around 2008 highlighted the need to monitor the "health" of financial institutions, and the increase in the trend towards defaults remains a good indicator of risk in banks, which has gained a lot of attention thanks to the association of default with financial instability (SAEED and IZZELDIN, 2014). This fact is linked to credit risk, which can be described as the probability of non-fulfillment of the payment promise made by the borrower at the time of contracting, or the potential financial loss resulting from a loan default (HUSCHER, 2017; SATHYE, 2005). Thus, the decision to grant credit is considered complex, since it involves aspects that go beyond the risk profile of the borrower and the operation, including the organization's credit policies and objectives, which requires strategic alignment with management (SILVA, 2014).

In this study, credit risk is defined as the possibility of losses associated with non-compliance by the counterparty with its obligations under the agreed terms, as based on NMC Resolution No. 4,557 (2017) - this risk being, therefore, the focus of analysis in this research.

Efficiency measures have been used as performance measures, especially in financial institutions. Technical efficiency is the ability to minimize the relationship between inputs and outputs, aiming to ensure the best use of the institution's resources (PEÑA, 2008). In the case of credit unions, the aim is then to maximize the benefits to the members.

Several studies have related efficiency and risk in banks (ALTUNBAS, CARBO, GARDENER et al., 2007; CARNEIRO, SALGADO JUNIOR and MACORIS, 2016; FIORDELISI, MARQUES-IBANEZ and MOLYNEUX, 2011; PASTOR and SERRANO, 2005; TAN and ANCHOR, 2017; TAN and FLOROS, 2018), but research on this topic related to credit unions is scarce and does not necessarily concern risk and efficiency (FREITAS, AMARAL and BRAGA, 2008; FRANCISCO, AMARAL and BERTUCCI, 2012; HUSCHER, 2017).

Given the relevance of credit risk analysis, credit unions have as their most relevant activity the concession of credit, which ensures the continuity of their operations (HUSCHER, 2017). In this context, this study will answer the following question: what is the relationship between credit risk and the technical efficiency of Brazilian credit unions in the period from 2008 to 2017 ? 
This is a current topic, which has an impact on society, given the activity of these companies. It also has effects on the perspective of the cooperatives themselves, subsidizing their strategic decisions and, additionally, contributing to the regulatory policies of these institutions, as well as to the academy, when investigating a topic that has not been investigated so far.

Our results show that greater credit risk generates lower efficiency of Brazilian credit unions, and also that the scenario of instability resulting from the retraction of the Brazilian economy from 2015 caused a reduction in their technical efficiency, despite the fact that, in the period of 2008 to 2017 have achieved, on average, a technical efficiency score of $99.78 \%$.

\section{RISKS AND EFFICIENCY IN FINANCIAL INSTITUTIONS}

Credit unions are exposed to the same risks as banks when it comes to financial intermediation, mainly because banking is characterized as a typically risky activity. Cooperatives, even though they do not have the purpose of accumulating profits, but rather provide services to their members, must stick to the efficient management of the risks inherent in their activity. The lack of control over risks directly affects the level of security and guarantees on the operations carried out, leading them to deviate from their main purpose, which is to guarantee efficiency in the provision of their services (FREITAS, AMARAL and BRAGA, 2008; PEREIRA, 2006).

Risk management is of singular importance for the survival and soundness of financial systems. For this reason, it is one of the main concerns of both institutions and world banking supervision, as highlighted by Stiglitz (1994) and Jorion (2003).

Kaupelytè and McCarthy (2006) emphasize that, in some cases, inadequate risk management can lead to the liquidation of individual credit unions or even the entire network of unions. Risk management in such institutions is often related to the development stages of credit unions. As they develop, professionalism and high standards of risk management should improve with the expansion of services and activities. This, in general, leads to an increase in the regulation of the activities of credit unions.

The CMN Resolution No. 4,557 (BRASIL, 2017) regulates that financial institutions must maintain a continuous and integrated risk management structure compatible with the business model, the nature of operations and the complexity of products, services, activities and institution's processes.

Financial institutions are subject to many different types of risks, but credit risk is the most significant for most of them, and is therefore the focus of the Basel Accord (1988).

Credit risk is defined, according to Resolution No. 4,557 (BRASIL, 2017), of the Brazilian National Monetary Council (CMN), as the possibility of losses associated with: (i) non-compliance by the counterparty with its obligations under the agreed terms; (ii) devaluation, reduced remuneration and expected gains in a financial instrument resulting from the deterioration of the credit quality of the counterparty, the intervening party or the mitigating instrument; (iii) restructuring of financial instruments; or (iv) costs of recovering exposures characterized as problematic assets, pursuant to art. 24.

Credit risk is linked to the probability of non-fulfillment of the payment promise made by the borrower at the time of contracting or to the potential financial loss resulting from the loan default (HUSCHER, 2017; SATHYE, 2005). This type of risk has been more related to bank failure problems, and is also one of the most common, since the activity of organizations such as banks and credit unions consists in granting loans (STUCHI, 2004).

The CMN Resolution No. 2682 (BRASIL, 1999) provides that financial institutions and other companies authorized to operate by the Central Bank of Brazil (BACEN) must classify credit operations, in an increasing order of risk, at the following rating levels: AA, A, B, C, D, E, F, G and H. Such classification is the responsibility of the institution holding the credit and must be carried out based on consistent and verifiable criteria.

Melo and Lima (2015) highlight that the problems that occurred in financial institutions around the world culminated, in many cases, in the bankruptcy of these organizations and highlighted the high risk scenario in which they operate. Thus, Freitas, Amaral and Braga (2008) emphasize the importance of risk management in credit unions. 
Several studies address credit risk in financial institutions. At the international level, Salas and Saurina (2002) compared the determinants of problematic loans from Spanish commercial and savings banks in the period from 1985 to 1997, taking into account macroeconomic and individual bank level variables. The authors found that the growth rate of the Gross Domestic Product (GDP), family indebtedness, the rapid expansion of credit or branches, inefficiency, the composition of the portfolio, size, financial margin, the capital index and market power are variables that explain credit risk. They also point out that there are significant differences between commercial and savings banks, confirming the relevance of the institutional form in the management of credit risk.

Sathye (2005) examined the effects of the introduction of internet banking tool transactions on the performance and risk profile of Australian credit unions, concluding that this adoption did not change their risk profile. Hackbarth, Miao and Morellec (2006) developed a framework for analyzing the impact of macroeconomic conditions on credit risk and the dynamic choice of capital structure. Initially, they observed that, when cash flows depend on current economic conditions, there is a benefit for companies to adapt their default and financing policies to the position of the economy in the business cycle phase.

Marcucci and Quagliariello (2009) investigated the relationship between credit risk and the business cycle, both at the aggregate and at the bank level, exploring an exclusive data set on the default rates of borrowers of Italian banks. The authors found that the effects of the business cycle on credit risk are most evident during the downturns, as well as cyclicality is also higher for banks with riskier portfolios.

Imbierowicz and Rauch (2014) investigated the relationship between liquidity and credit risk. They used commercial banks in the United States during the period 1998 to 2010 to analyze the relationship between these two sources of risk at the bank's institutional level and how that relationship influences the probabilities of default. The results showed that both risk categories did not have an economically significant, contemporary or time lagged reciprocal relationship. However, they did influence the probability of bank default.

More recently, Musau, Muathe and Mwangi (2018) analyzed the effect of financial inclusion on credit risk and the mediating effect of the competitiveness of commercial banks in Kenya. The study concluded that the availability, accessibility and use of banks had a significant effect on credit risk. The bank's competitiveness was found to partially mediate the relationship between financial inclusion and credit risk.

In the national scenario, research by Costa (2005); Dantas, Rodrigues, Rodrigues et al. (2010); Francisco, Amaral and Bertucci (2012); Freitas, Amaral and Braga (2008); Huscher (2017) and Lima, Fonseca, Silveira et al. (2018) are examples of works that dealt with this subject.

Costa (2005) aimed to create a specific corporate rating model for agricultural credit unions, based on the analysis of the bibliography on credit risk. Freitas, Amaral and Braga (2008) analyzed the impacts of the process of converting a rural credit union into a freely admitted credit union, characterizing the liquidity and credit risks and their influence on the financial sustainability of that cooperative. As a result, they found that the cooperative did not give the necessary importance to risk management and analysis.

In an investigation in Brazilian financial institutions, Dantas, Rodrigues, Rodrigues et al. (2010) aimed to assess the degree of transparency of the credit risk practices, having as reference the qualitative and quantitative disclosures required by the Basel II Agreement. The authors realized that the degree of disclosure showed gradual and steady growth in the period from 2001 to 2008, but it still serves less than $40 \%$ of the required items. Francisco, Amaral and Bertucci (2012) sought to analyze, within the scope of credit unions, those that generate the highest risk of default, based on the profile of the member, as well as which strategies could be pointed out to avoid possible failures in the next analysis. Thus, it was concluded that the most relevant variables to identify the default risk were the gross monthly income and the amount released in the granting of credit.

Huscher (2017) sought to develop a credit rating model for evaluating credit unions. Through a multinomial logistic regression, it was possible to develop a model with four classifications: A (low), B (low medium), C (medium) and D (high), with an overall predictive power of $80.1 \%$ - the worst risk (D), $90.9 \%$, and best (A), $89.9 \%$, serving as a tool to be used by financial institutions for risk analysis of credit unions. In addition, Lima, Fonseca, Silveira et al. (2018) aimed to identify the determinants of credit 
ratings in publicly traded Brazilian banks in the period from 2006 to 2015. In summary, their findings showed that variables related to the performance, liquidity, suitability / quality of the asset and size had an impact statistically significant in the rating level of banks. There was also a deterioration in credit ratings, which could be linked to the retraction of the economy, observed in Brazil during the analysis period of the study.

Based on the parameters brought by the Basel Committee and on the understanding that the credit risk is linked to the probability of non-fulfillment of the payment promise made by the borrower, at the time of contracting, or to the potential financial loss resulting from the loan default. , many works (AKWAA-SEKYI, KOFI and GENÉ, 2017; ANNIBAL, 2009; CHANG and CHIU, 2006; CHAIBI and FTITI, 2015; CUCINELLI, DI BATTISTA, MARCHESI et al., 2018; FERREIRA, OLIVEIRA, SANTOS et al., 2011; FIORDELISI, MARQUES-IBANEZ and MOLYNEUX, 2011; FRANCISCO, AMARAL and BERTUCCI, 2012; MUSAU, MUATHE and MWANGI, 2018; SALAS and SAURINA, 2002; TABAK, CRAVEIRO and CAJUEIRO, 2010) adopted the variables "bad debt" and "estimated loss with credits doubtful accounts" as proxies of credit risk.

Annibal (2009) recalls that although a financial institution may not know in advance the losses to which it will be subjected in a given period, it can, given its experience, estimate a level of loss for the period. Pastor and Serrano (2005) considered the allowance for loan losses as a proxy for credit risk on the assumption that the greater the volume of bad loans, the greater the corresponding provision. In the same direction, Pastor (2002) argued that, in loan loss provisions, the company implicitly considers the risk associated with each problematic loan.

Regarding default, Cucinelli, Di Battista, Marchesi et al. (2018) describe that this measure is widely used in other relevant studies to represent an institution's accumulated credit risk, considering the materialization of that risk, as considered by Fiordelisi, Marques-Ibanez and Molyneux (2011). Thus, Chang and Chiu (2006) also reinforced that many studies pointed out that both default and the estimated loss for doubtful loans are indicative of credit risk, as adopted in the present research.

Among the various possible classes for performance measuring, there are accounting/financial-based measures, customer or market-based, innovation and learning-based, social, environmental, behavioral/situational-based and aggregate or general measures, as well as those related to internal processes - the latter include efficiency analysis, which show how well resources have been used to generate revenue and indicate the existence of wasted resources. The performance analysis includes evaluations of financial information and non-financial aspects. It must be considered that the cooperative sector is composed of a peculiar organizational type, which can act as a promoter in social development and, at the same time, must remain economically viable by being competitive with other organizations, in addition to having to deal with expectations of its members, signaling the adherence of the efficiency analysis in terms of performance, in the context of these institutions.

Internationally, some studies have investigated the relationship between risk and efficiency. Pastor and Serrano (2005) analyzed the efficiency and credit risk of banks in the major economies in the euro area and found that risk adjustments are important in the case of profit efficiency, but not in cost efficiency. Altunbas, Carbo, Gardener et al. (2007) analyzed the relationship between capital, risk and efficiency for a sample of European banks between 1992 and 2000. The authors did not find a positive relationship between inefficiency and banking risk. In the case of cooperative banks, they found that capital levels were inversely related to risk and that inefficient banks had lower levels of capital.

Fiordelisi, Marques-lbanez and Molyneux (2011) also evaluated the relationship between efficiency, capital and risk of European commercial banks. The conclusions pointed out that lower banking efficiency, in relation to costs and revenues, causes greater banking risk, and that increases in banking capital precede improvements in cost efficiency. The results indicated that more efficient banks end up becoming more capitalized, and that higher levels of capital tend to have a positive effect on efficiency levels. The authors point out that such findings have important implications for the prudential supervision of banks and highlight the importance of obtaining long-term efficiency gains to support financial stability objectives.

Sarmiento and Galán (2017) presented evidence about the influence of risk on banking efficiency in emerging markets, and identified heterogeneity in the way that risk affects banks with different characteristics. The effects of risk on efficiency vary with size and affiliation. Another result of the study was that large and foreign banks benefited more from greater exposure to credit and market risks, while domestic and small banks were more capitalized. Tan and Floros (2018) tested the interrelationships between risk, competition and efficiency in the Chinese banking sector between 2003 and 2013. The relationships found were that the most efficient Chinese commercial banks had a higher credit and insolvency risk, but less risk liquidity and capital. 
Referring to the national literature, the work of Tabak, Craveiro and Cajueiro (2010) sought to identify the causal relationship between non-performing loans and bank efficiency in Brazilian institutions. The authors found that an increase in the level of non-performing loans can be explained by a decrease in efficiency, probably also manifested in failures in the management of risk assessment. Carneiro, Salgado Junior and Macoris (2016) assessed the efficiency level of 99 financial institutions that operated in the Brazilian financial market in 2013. The authors identified 22 with a higher degree of efficiency, with some heterogeneity in relation to the origin of capital, size and sector of activity. On the other hand, an indication was identified that there is a directly proportional positive relationship between the credit rating and the efficiency of the institutions analyzed.

Similarly, Cava, Salgado, Branco et al. (2016) evaluated the efficiency of banks that operated in the Brazilian market in 2013. The results indicated that large banks have the highest average score, suggesting that they are more efficient. Federal public banks had the highest average efficiency score, compared to other banks. Those with foreign capital and participation had high average scores. Those operating in foreign currency had the best average efficiency scores. As for risk classification, those classified as AAA had higher average efficiency scores, suggesting that banks with better services have more solid results and better classification.

Through the survey of studies related to the subject in question, until now, there has been no work that has dealt with the relationship between efficiency and risk in a focused way in Brazilian credit unions. This research will contribute in order to reduce the gap in the national literature on the subject.

The analysis of the works already published on the subject, in Brazil and in other countries, allowed the prior identification of the variables for our proposed model of efficiency analysis of credit unions: total deposits, personnel expenses, funding expenses, administrative expenses and others, as input variables, in addition to credit operations and surpluses as output. As shown below, the model variables were validated and complemented by a panel of specialists.

\section{METHODOLOGY}

\section{Sample}

The semiannual accounting data for Brazilian credit unions were obtained from the database of the Financial Institutions Accounting Plan (Cosif), available on the Bacen website. We worked with the period from 2008 to 2017. The final sample was made up of 450 singular credit unions (46.5\%) which resulted in 9 thousand observations. The credit unions excluded from the sample were those classified as capital and loans - since they do not collect deposits -, as well as those that presented missing information in some analyzed period. Therefore, a balanced panel was used. Credit Unions that carried out mergers and spin-offs were also raised on the Bacen website, in the authorization reports and corporate changes of financial institutions.

A questionnaire was used as an instrument in this research. Initially, the pre-test was performed. Afterwards, this research instrument was sent to specialists in credit unions, in addition to Bacen technicians. This instrument aimed to identify the factors considered adequate for the evaluation of the technical efficiency of credit unions, in order to verify whether the variables pointed out in the literature represented, in fact, the reality of the analyzed institutions, in addition to the possibility of incorporating new variables into the analysis.

In this stage, we used "snowball" sampling, in which initially some people with the necessary profile for the research are located. Thus, the questionnaire was sent to 42 individuals at first, and their contacts were obtained in a majority, together with registrations and indications made in consultations with Bacen. Subsequently, initial respondents were asked to indicate new contacts with the desired characteristics, from their own personal network, and so on. Thus, the sample can grow with each cycle, which is the interest of researchers. At the end of this stage, 17 respondents collaborated. We highlight their great contribution, which allowed bringing essential variables to the analysis of technical efficiency in Brazilian credit unions, promoting the interaction of the experience of professionals and users of these institutions with academic work. Table 1 shows the profile of the respondents. 
Table 1

Respondents profile

\begin{tabular}{|c|c|}
\hline Area of expertise & $\%$ \\
\hline Controllership and finance in credit unions & 17.65 \\
\hline Credit unions board manager & 23.5 \\
\hline Credit unions manager & 11.8 \\
\hline Professionals linked to the Bacen & 11.76 \\
\hline Others * & 35.29 \\
\hline Time of work in credit unions & $\%$ \\
\hline Less than 10 years & 18 \\
\hline 10 to 20 years & 41 \\
\hline Over 20 years & 18 \\
\hline Do not work in credit unions or have not responded & 23 \\
\hline Credit Union Member & $\%$ \\
\hline Yes & 76.5 \\
\hline No & 23.5 \\
\hline Geographic distribution & $\%$ \\
\hline South & 29.4 \\
\hline Southeast & 23.5 \\
\hline Midwest & 17.7 \\
\hline Did not answer & 29.4 \\
\hline
\end{tabular}

Note: * Includes professionals from other financial institutions, market specialists and the Credit Unions Guarantee Fund.

Source: Research results.

\section{ANALYTICAL MODEL}

\section{Data Envelopment Analysis}

Technical efficiency was chosen to measure the performance of Brazilian credit unions in this study. The first investigations on the theme go back to the seminal work of Charnes, Cooper and Rhodes (1978) and Farrel (1957).

Data Envelopment Analysis (DEA) is a non-parametric technique that uses a linear programming model to assess the relative efficiency of a set of homogeneous entities - Decision Making Units (DMUs) - known as decision makers that use the same inputs and produce outputs similar. It is based on the concept of technical efficiency proposed by Farrell (1957) and was developed mathematically by Charnes, Cooper and Rhodes (1978). The method identifies the DMUs that represent the best practices by comparing each DMU with all possible linear combinations of the other units. The group of efficient DMUs forms the efficient limit and the radial distance from the rest of the entities to that limit, identifying inefficient behavior (CAMPILLO, SANTOS and FERNÁNDEZ, 2017).

Based on previous studies in the context of credit unions, such as Bittencourt, Bressan, Goulart et al. (2017); Bressan, Lopes and Menezes (2013); Souza, Braga and Ferreira (2011) this study uses a model with variable returns to scale and with product orientation, proposed by Banker, Charnes and Cooper (1984), since it aims to evaluate the capacity of credit unions to provide 
maximum possible return to its members and society, considering the resources available. The estimator is obtained by solving the following linear programming problem (Equation I), which must be evaluated $n$ times, one for each DMU in the sample:

$$
\hat{\delta}=\max \hat{\delta}_{i \lambda}\left\{\delta>0 \mid \hat{\delta}_{i} y_{i} \leq \sum_{y=1}^{n} y_{i} \lambda ; x_{i} \geq \sum_{y=1}^{n} x_{i} \lambda ; \sum_{y=1}^{n} \lambda_{i}=1 ; \lambda \geq 0\right\} ; i=1 \ldots, n \text { DMUs (I) }
$$

where $Y_{i}$ is the output vector; $X_{i}$ is the input vector; $\lambda$ is a vector $n \times 1$ of constants that measure the weights used to calculate the location of inefficient DMUs to become efficient; $\hat{\delta}_{i}$ is the efficiency index for DMU $i$. Thus, if $\hat{\delta}_{i}=1 \mathrm{DMU} i$ is efficient and if $\hat{\delta}_{i}<1 \mathrm{DMU}$ i is relatively inefficient.

The two-stage DEA model was used. In the first stage, efficiency scores were estimated using a conventional DEA model based on a set of input and output variables. Then, the DEA efficiency estimates are regressed in the second stage, via the Tobit model, with the explanatory variables. Table 2 shows the variables effectively used in the DEA model, chosen according to the applicable literature, as well as the expertise and validation of the specialists consulted through the questionnaire tool.

Table 2

Variables that made up the DEA model in the first stage

\begin{tabular}{|c|c|c|c|}
\hline & Variables & Abbreviation & Cosif Codes \\
\hline \multirow{9}{*}{ 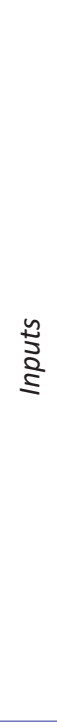 } & Total deposits & TD & [41000007] \\
\hline & Funding expense & $\mathrm{FE}$ & [81100008] \\
\hline & Borrowing and onlending expenses & $\mathrm{BOE}$ & [81200001] \\
\hline & $\begin{array}{l}\text { Expenses with bonds and securities } \\
\text { Instrumentos Financeiros Derivativos }\end{array}$ & EBS & [81500000] \\
\hline & Participation expenses & PE & [81600003] \\
\hline & Provisioning and equity adjustments & PEA & [81800009] \\
\hline & Other operating expenses & $\mathrm{OOE}$ & [81900002] \\
\hline & Administrative expenses & $\mathrm{AE}$ & [81700006] \\
\hline & Personnel expenses & PerE & $\begin{array}{c}{[81718005]+} \\
{[81727003]+} \\
{[81730007]+} \\
{[81733004]+} \\
{[81736001]+} \\
{[81737000]+} \\
{[81990201]}\end{array}$ \\
\hline \multirow{8}{*}{$\frac{0}{0}$} & Credit operations & $\mathrm{CO}$ & {$[16000001]$} \\
\hline & Surplus & SU & [61700002] \\
\hline & Reserve & RS & $\begin{array}{l}{[61300000]} \\
+[61400003] \\
+[61500006]\end{array}$ \\
\hline & Income from credit operations & ICO & [71100001] \\
\hline & Income from interbank liquidity applications & IILA & [71400000] \\
\hline & $\begin{array}{l}\text { Income bonds and securities } \\
\text { Instrumentos FinPnceiros DeriSativos }\end{array}$ & IBS & [71500003] \\
\hline & Income from servisse & IS & [71700009] \\
\hline & Other operating income & OOI & [71900005] \\
\hline
\end{tabular}

Source: Elaborated by the authors. 


\section{Second stage: Tobit model}

Taking into account the wide range of possible statistical treatments for performing the second stage analysis of DEA, Hoff (2007) and Turner, Windle and Dresner (2004) consider that the Tobit regression model is a consistent method, in addition to be the most used by researchers in the field of financial institutions (AMOAH, OHENE-ASARE and ABOAGYE, 2018; BRESSAN, LOPES and MENEZES, 2013; CAMPILLO, SANTOS and FERNÁNDEZ, 2017; KAR and DEB, 2018; STAUB, SOUZA and TABAK, 2010; SUN, SUN and RABARISON, 2018). The adequacy of the model refers to situations in which the dependent variable is constituted by a continuous and limited sample, as occurs with the efficiency scores calculated by DEA, since these values correspond to the continuous interval defined in [0; 1], assuming a positive probability for value 1 (HOFF, 2007).

\section{Variables and specification of the Tobit model: credit risk (CRDO; CRELALL)}

The relationship between credit risk and efficiency is not conclusive in the literature. Some research has found that the higher the credit risk, the lower the institution's efficiency (ALTUNBAS, CARBO, GARDENER et al., 2007; BRANCO, SALGADO, CAVA et al., 2017; TABAK, CRAVEIRO and CAJUEIRO, 2010). On the other hand, Hou, Wang and Zhang (2014); Tan and Anchor (2017); Tan and Floros (2018) found a relationship between the higher the credit risk, the greater the efficiency of the institution. In this study, the same behavior is expected for Brazilian banks (TABAK, CRAVEIRO and CAJUEIRO, 2010), that is, it is assumed that credit unions with lower credit risk will be those with the highest technical efficiency. The credit risk variables will be obtained as follows:

1. CRDO: This indicator will consider a credit operation that has overdue installments for more than 90 days in default (BANCO CENTRAL DO BRASIL, 2017; BASEL II, 2006; CUCINELLI, DI BATTISTA, MARCHESI et al., 2018; FIORDELISI, MARQUES-IBANEZ and MOLYNEUX, 2011; FINANCIAL STABILITY REPORT, 2017) and will be computed as in Equation II:

$$
\mathrm{CRDO}=\frac{\text { Total defaulted operations }}{\text { Total credit operations }} \text { (II) }
$$

2. CRELALL: according to CMN Resolution No. 2,682/2009, the provision must be constituted monthly to cover doubtful accounts. The resolution determines that the provision percentages range from a minimum of $0.5 \%$ (level A) to $100 \%$ (level $\mathrm{H}$ ). Thus, the CRELALL variable used as a proxy to analyze credit risk follows the direction of the CNM resolution, which was also adopted by other authors (CHO and CHUNG, 2016; CUCINELLI, DI BATTISTA, MARCHESI et al., 2018; SATHYE, 2005; TOLEDO, KROENKE and SOTHE, 2009) and obtained according to Equation II

$$
\text { CRELALL }=\frac{\text { Estimated loss on allowance for loan losses for the period }}{\text { balance of credit operations }} \text { (III) }
$$

3. Size (NLSIZE): Size is a control variable and will be measured using the natural logarithm of the total asset. For Andries, Cãpraru and Nistor (2018); Campillo and Santos (2016); Campillo, Santos and Fernández (2017), larger institutions tend to have higher levels of efficiency. The opposite relationship was found by Cázares, Sáez and Marco (2013), as well as by Branco, Salgado, Cava et al. (2017). Thus, the relationship between the variable size and the efficiency of credit unions can be negative or positive.

4. Diversification (DIV): For Sang (2017), the relationship between bank efficiency diversification remains inconclusive. For Krakah and Ameyaw (2010), the services provided by financial institutions outside their traditional activities favor the performance of these institutions. For Gischer and Juttner (2001), the provision of services outside the main activity has a negative relationship with performance, since the market for these services tends to be more competitive compared to the market for traditional activities. For credit unions, Vieira (2016) indicated that diversification provides benefits. In this scenario, this variable may have a positive or negative relationship with efficiency and will be calculated according to Equation IV.

$$
\text { DIV }=\frac{\text { Income not arising from credit operations }}{\text { Operating income }} \text { (IV) }
$$


5. Recession dummy (DumR): Campillo, Santos and Fernández (2017) concluded that the crisis situation had a negative impact on the efficiency of Spanish credit unions. Glass, McKillop, Quinn, and Wilson (2014) emphasize that financial organizations must be more efficient, especially in times of crisis, since they are inserted in competitive environments. In Brazil, the economic recession that started in 2015 was the biggest economic downturn in the last 25 years (INSTITUTE OF APPLIED ECONOMIC RESEARCH - IPEA, 2015), negatively influencing the performance of Brazilian credit unions (CORDEIRO, BRESSAN, LAMOUNIER et al., 2018). Thus, the recession dummy assumes a value of 1 when the data refer to the period from 2015 to 2017; otherwise, its value is 0 .

6. Time of existence (TE): Firms' capacities are formed by the experience obtained over time (CÁZARES, SÁEZ and MARCO, 2013). Thus, it is expected that the longer the cooperative exists, the greater its market and managerial experiences should be, with the expectation that this variable is positively related to efficiency.

7. Service points (SP): For Campillo, Santos and Fernández (2017), institutions with a higher number of service points would be more efficient. However, it must be considered that the behavior of new generations, the entry of new technologies and the ways in which organizations relate to their customers have been changing over the years. In Brazil, while banks reduced the number of physical branches in 2017, credit unions affiliated to the Sicoob system registered an expansion of 5.7\% between 2016 and 2017, with the creation of 165 new points of service, becoming the fifth largest network of service in Brazil (MOTTA, 2018). Despite the potential to expand service to cooperative members, the new points may also increase operating costs. Thus, the number of service points can have a positive or negative relationship with efficiency.

8. Acquisition dummy (DumACQ): Vieira (2016) found that the merger negatively affected the performance of credit unions. In Brazil, there has been a movement of incorporations/mergers by credit unions, including incentives by the regulator itself, thus allowing better conditions of competitiveness with the traditional banking system (BANCO CENTRAL DO BRASIL, 2015). A dummy with a value of 1 was assumed for the credit unions that were incorporated; otherwise, the value is 0 .

9. Dummy with regional effect (DumSOUTH, DumNORTHEAST, DumNORTH, DumCEN): Several studies have addressed the existence of the so-called "regional effect", which suggests that the efficiency of institutions varies according to their geographic location within a given country (CAMPILLO, SANTOS and FERNÁNDEZ, 2017; GLASS, MCKILLOP, QUINN et al., 2014; WORTHINGTON, 1999). DumSOUTH = dummy with a South regional effect; DumNORTHEAST = dummy with a Northeast regional effect; DumNORTH = dummy with a North regional effect; DumCEN = dummy with a Central-West regional effect. It is, therefore, a binary control variable in this research.

Thus, in the second stage of DEA, two regression models were used with panel data estimated by the Tobit model, according to Equations V and VI.

$$
\begin{aligned}
& \mathrm{Y} *_{\mathrm{it}}=\beta_{0}+\beta_{1} \mathrm{CRDO}_{\mathrm{it}}+\beta_{2} \mathrm{SIZE}+\beta_{3} \mathrm{DIV}_{\mathrm{it}}+\beta_{4} \mathrm{TE}_{\mathrm{it}}+\beta_{5} \mathrm{SP}_{\mathrm{it}}+\beta_{6} \mathrm{DumR}_{\mathrm{it}}+\beta_{7} \mathrm{DumACQ}_{\mathrm{it}}+ \\
& \beta_{8} \text { DumSOUTH }_{i t}+\beta_{9} \text { DumNORTHEAST }_{\text {it }}+\beta_{10} \text { DumNORTH }_{\text {it }}+\beta_{11} \text { DumCEN }_{\text {it }}+u_{i t} \text { (V) }
\end{aligned}
$$

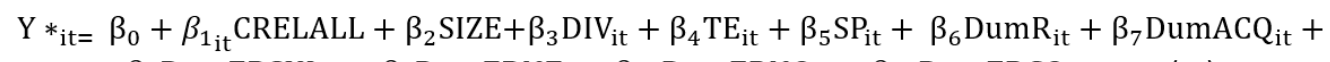

$$
\begin{aligned}
& \beta_{8} \text { DumERSUL }_{i t}+\beta_{9} \text { DumERNE }_{i t}+\beta_{10} \text { DumERNO }_{i t}+\beta_{11} \text { DumERCO }_{i t}+u_{i t}(\mathrm{VI})
\end{aligned}
$$

Being:

$Y^{*}=$ Technical efficiency scores of credit unions obtained through the DEA methodology;

$\beta_{0}=$ Model intercept;

$i=1, \ldots, N$ Brazilian credit unions;

$t=1, \ldots, T$ semesters and refers to the period from 2008-1 to 2017-2;

$\beta_{i j}$ are the angular coefficients estimated for each independent variable, described previously;

$\mathrm{u}_{i t}=\alpha_{i}+\varepsilon_{i t}$ is the compound error term where is the unobserved individual effect and is the random error term. 


\section{Procedures adopted to estimate the Tobit model}

To obtain the final Tobit model, the following procedures were adopted: tests of individual significance of the explanatory variables and comparison between restricted and unrestricted models using the LRtest. The test showed that the restricted model was the most suitable for both the RCINAD risk proxy and the RCPECLD proxy. Finally, models $(\mathrm{V})$ and $(\mathrm{VI})$ were replaced by restricted models (VII) and (VIII).

$$
\begin{aligned}
& \mathrm{Y} *_{\mathrm{it}}=\beta_{0}+\beta_{1} \mathrm{CRDO}_{\mathrm{it}}+\beta_{3} \mathrm{DIV}_{\mathrm{it}}+\beta_{4} \mathrm{TE}_{\mathrm{it}}+\beta_{5} \mathrm{SP}_{\mathrm{it}}+\beta_{6} \mathrm{DumR}_{\mathrm{it}}+\mathrm{u}_{\mathrm{it}} \text { (VII) } \\
& \mathrm{Y} *_{\mathrm{it}}=\beta_{0}+\beta_{1} \mathrm{CRELALL}_{\mathrm{it}}+\beta_{3} \mathrm{DIV}_{\mathrm{it}}+\beta_{4} \mathrm{TE}_{\mathrm{it}}+\beta_{5} \mathrm{SP}_{\mathrm{it}}+\beta_{6} \mathrm{DumR}_{\mathrm{it}}+\mathrm{u}_{\mathrm{it}} \text { (VIII) }
\end{aligned}
$$

\section{ANALYSIS AND DISCUSSION OF RESULTS}

The Brazilian credit unions surveyed in the period from 2008 to 2017 had an average of three service points and 14.38 years of existence - the youngest cooperative with approximately 1.5 years of existence and the oldest, with 51 . The proxies of credit risk CRDO and CRELALL indicated large differences between credit unions. However, in general, the credit unions surveyed had an average efficiency score of $99.78 \%$ (Table 3).

Table 3

Descriptive statistics of the variables of the second stage of DEA

\begin{tabular}{lccccccc}
\hline & $\mathrm{Y}$ & $\mathrm{SP}$ & $\mathrm{TE}$ & $\mathrm{DIV}$ & $\mathrm{CRDO}$ & CRELALL & Total assets \\
\hline Mean & $99,78 \%$ & 3,0742 & 172,6449 & 0,3792 & 19033,389 & 19100,0537 & $1,7674 \mathrm{e}^{+11}$ \\
\hline Standard deviation & 0.28994 & 4,4330 & 88,5206 & 0,1481 & 645914,233 & 662517,5571 & $4,2677 \mathrm{e}^{+11}$ \\
\hline Minimum & $99,17 \%$ & 1 & 0,53 & 0,0019 & 0 & 0 & 6757,22 \\
\hline Maximum & $100 \%$ & 36 & 612 & 1 & $3,90 \mathrm{e}^{+7}$ & $3,80 \mathrm{e}^{+7}$ & $6,578 \mathrm{e}^{+12}$ \\
\hline CV & 0.2905 & 1,4420 & 0,5127 & 0,3906 & 33,936 & 34,6867 & 2,4148 \\
\hline
\end{tabular}

Notes: The time of existence (TE) was considered (in months). CV = Coefficient of variation. $Y=$ Technical efficiency score. Source: Research results.

The LR and Wald tests indicated that the Tobit 1 and 2 models were globally valid (Table 4). In both, the higher the credit risk, the lower the technical efficiency of Brazilian credit unions, a result compatible with what was expected in this research and which corroborates other studies, such as Branco, Salgado, Cava et al. (2017), Carneiro, Salgado Junior and Macoris (2016), Cava, Salgado, Branco et al. (2016), Fiordelisi, Marques-lbanez and Molyneux (2011), Hou, Wang and Zhang (2014), Sathye (2005) and Tabak, Craveiro and Cajueiro (2010). 
Table 4

Results of the Tobit Model estimates in the second stage of DEA

\begin{tabular}{|c|c|c|c|c|}
\hline Variables & Model 1 & Dy/Dx Model 1 & Model 2 & Dy/Dx Model 2 \\
\hline CRDO & $-2.56 e^{-10 * * *}$ & $-1.11 \mathrm{e}^{-10 * * *}$ & & \\
\hline CRELALL & & & $-2.73 e^{-10 * * *}$ & $-1.18 e^{-10 * * *}$ \\
\hline SP & $-0.0000496 * * *$ & $-0.0000216 * * *$ & $-0.0000499 * * *$ & $-0.0000217 * * *$ \\
\hline TE & $3.16 \mathrm{e}^{-6 * * *}$ & $1.37 \mathrm{e}^{-6 * * *}$ & $3.17 \mathrm{e}^{-6 * * *}$ & $1.38 e^{-6 * * *}$ \\
\hline DIV & $0.0019144 * * *$ & $0.0008314 * * *$ & $0.0019193^{* * *}$ & $0.0008334 * * *$ \\
\hline DumR & $-0.0005983^{* * *}$ & $-0.0002599 * * *$ & $-0.0005983^{* * *}$ & $-0.0002598 * * *$ \\
\hline Constant & $0.9978937 * * *$ & & $0.9978913 * * *$ & \\
\hline Wald (chi) & $64.67 * * *$ & & $65.11^{* * *}$ & \\
\hline LR(Likelihood-ratio test of sigma) & $2008.4 * * *$ & & $2014.5^{* * *}$ & \\
\hline sigma_u & $0.0024161 * * *$ & & $0.0024201 * * *$ & \\
\hline sigma_e & $0.0032925^{* * *}$ & & $0.0032918^{* * *}$ & \\
\hline Rho & 0.3500124 & & 0.3508661 & \\
\hline No. of observations & 9000 & & 9000 & \\
\hline No. of Groups & 450 & & 450 & \\
\hline
\end{tabular}

Notes: Statistically significant at *10\%; **5\%; ***1\%. Model 1: Default (CRDO). Model 2: Estimated loss on loan losses for the period (CRELALL). Dy / Dx = Marginal Effect.

Source: Research results

This negative relationship between credit risk and efficiency may indicate that managers, averse to risk, would tend to increase operating expenses for the evaluation and monitoring of loans, in an attempt to control the increase in defaults, which would have a negative impact in the bank's efficiency measure. On the other hand, it would have a positive effect on defaults in credit portfolios, in order to reduce it. Thus, risk-averse managers would tend to increase spending on monitoring to control delinquent credits, which would reduce banking efficiency (TABAK, CRAVEIRO and CAJUEIRO, 2010).

Another justification would be the fact that the credit risk faced by credit unions is caused mainly by exogenous components, such as economic downturns. As a result, institutions would incur higher costs to monitor the increase in defaults, thereby reducing efficiency. This drop in technical efficiency may have another causal relationship and be caused by an unsatisfactory performance by managers, who could not correctly monitor the loan portfolio, affecting the quality of loans and generating high default rates, which would result in losses to the cooperative and enhance a decrease in their efficiency indicators (BERGER and DEYOUNG, 1997).

It was also found that the greater the number of service points, the lower the efficiency scores (Table 4). The increase in service points can increase operating costs and, consequently, hinder an improvement in the institution's efficiency. However, it is a strategic decision that needs to take into account the well-being of the members and their interests. In this case, similarly, the recession dummy had the behavior of negatively impacting the technical efficiency of Brazilian credit unions. Although these institutions maintained stable or growing equity values during the national financial crisis, the period of economic recession negatively impacted the performance indicators related to efficiency, corroborating Cordeiro, Bressan, Lamounier et al. (2018), which showed that the economic recession that started in 2015 in Brazil influenced the performance of credit unions.

The cooperative's existence and the diversification of financial products had a positive impact on the credit unions' efficiency. According to the estimated models, a more experienced institution, with more time in the market, can increase its efficiency score compared to a newer one. The experiences acquired by the knowledge of the market, as well as the experiences in relation to the proper functioning, can contribute so that these credit unions have better results in terms of maximizing their benefits, spending the least possible volume of resources for their activities and strategic decisions. 
Still in this direction, diversification has proved to be a strategic practice within the scope of cooperative institutions. The more diversified, the better the efficiency scores tend to be, that is, an increase in diversification also represents an increase in cooperative efficiency, corroborating the findings of Sathye (2005) and Sang (2017), which also obtained a positive relationship between diversification and technical efficiency.

It was observed, through the analysis of the coefficients (Table 4), that some exogenous variables, such as DIV and SP, were more impactful in efficiency than the credit risk itself, although all of them behaved in a statistically significant way. These are variables that are more closely related to the institutions' expense and revenue accounts, which could contribute to this impact occurring more sharply in efficiency scores, to the detriment of the risk proxies themselves, which have a certain measure of uncertainty in their structures, compromising to a lesser degree technical efficiency. Furthermore, the credit portfolios of the credit unions have been made up essentially of credits with better risk ratings. It was observed, in the period from 2013 to 2017, that the portfolio of individual institutions remained mostly classified in risk levels A and $B$, which would also justify the lower impact of credit risk on the efficiency of financial credit unions (BANCO CENTRAL DO BRASIL, 2019b).

The marginal effects found were similar in both models, with no significant variations in both estimates. Even having presented small values, in percentage terms, they are statistically relevant and signal the impact of their respective variables on the technical efficiency of the credit unions.

\section{FINAL CONSIDERATIONS}

Proper risk management and the maintenance of satisfactory performance are important factors for the continuity of any institution, and this is not different for credit unions.

This study analyzed the relationship between credit risk and the efficiency of Brazilian credit unions. It used the DEA methodology in two stages to estimate the efficiency scores of 450 institutions contrywide. The findings of the first stage of DEA indicated that the average of the efficiencies in the whole period was $99.78 \%$ for the analyzed credit unions. Specialists were consulted for the construction and validation of efficiency scores, which is a contribution of this study in relation to the others.

In the second stage of DEA, through Tobit, the models indicated a negative and significant relationship between credit risk, measured by CRDO and CRELALL, and the technical efficiency of financial credit unions, in line with the results of Tabak, Craveiro and Cajueiro (2010) for Brazilian banks. This result can be explained by the fact that managers start to be risk averse and tend to increase operating expenses for the evaluation and monitoring of loans, in an attempt to control the increase in defaults, which negatively impacts the cooperative efficiency.

The service points and recession dummy variables also showed a statistically significant and negative relationship with efficiency, denoting that, despite larger service networks having the potential to serve a greater number of users, they can increase operating costs and become in terms of efficiency. An alternative, in this case, would be the investment in information technologies, creating the possibility of using internet banking applications and online services, but always taking into account the interest and well-being of the members. In addition, in the period of Brazilian economic downturn between 2015 and 2017, credit unions were not immune, as the recession dummy indicated the negative impact on average efficiency scores.

Likewise, the experience acquired by the cooperative, measured by its existence and the diversification of financial products, had positive impacts on efficiency scores, which indicates that credit unions that manage to maintain continuity in the market and diversify their products they optimize resources and, consequently, generate more benefits to their members. 
It is suggested, for future research, to evaluate the profile of managers regarding the aversion or not to credit risk in credit unions, as well as to discuss, in the perspective of these managers, the main motivating factors of credit risk in credit unions and how the regulations of the Brazilian National Monetary Council (CMN) impact this minimization of risk and the increase or not of regulatory costs, relating these issues to the technical efficiency of Brazilian credit unions. In technical terms, it is also suggested to consider Malmquist's meta-frontier analysis, along with bootstrap regression, for the statistical inference of efficiency estimators, since in some cases the results found through traditional DEA estimation can be impacted by sample bias and would tend to diverge from those that would be found if the true production frontier was used. In this case, the bootstrap technique allows supporting the identification of such problems and filtering the relevant information in the results (AZAD, MUNISAMY, MASUM et al., 2017; BARROS and TENORIO JUNIOR, 2020).

\section{ACKNOWLEDGEMENT}

The authors thank CAPES for funding this research. 


\section{REFERENCES}

AKWAA-SEKYI, E. K.; GENÉ, M. J. Internal controls and credit risk relationship among banks in Europe. Intangible Capital, v. 13, n. 1, p. 25-50, 2017.

ALTUNBAS, Y. et al. Examining the relationships between capital, risk and efficiency in European banking. European Financial Management, v. 13, n. 1, p. 49-70, 2007.

AMOAH, B. et al. Technical efficiency: the pathway to credit union cost efficiency in Ghana. Managerial Finance, v. 44, n. 11, p. 12921310, 2018.

ANDRIEȘ, A. M.; CĂPRARU, B.; NISTOR, S. Corporate governance and efficiency in banking: evidence from emerging economies. Applied Economics, v. 50, n. 34-35, p. 3812-3832, 2018.

ANNIBAL, C. A. (2009). Inadimplência do setor bancário brasileiro: uma avaliação de suas medidas (Working Papers Series, 192). Brasília, DF: Banco Central do Brasil. Available at: <https://ideas.repec.org/p/ bcb/wpaper/192.html>. Accessed on: Nov. 18, 2020.

AZAD, M. A. K. et al. Bank efficiency in Malaysia: a use of malmquist meta-frontier analysis. Eurasian Bus Ver, v. 7, n. 2, p. 287-311, 2017.

BANCO CENTRAL DO BRASIL. Plano de Ação para Fortalecimento do Ambiente Institucional: Relatório 2012-2014. Parceria Nacional para Inclusão Financeira. Brasília, DF: Banco Central do Brasil, 2015. Available at:<http://www.bcb.gov.br/pec/appron/apres/Relat\%F3rio\%20PNIF\%20 \%20Br.\%200462.pdf>. Accessed on: Nov. 18, 2020.

BANCO CENTRAL DO BRASIL. Relatório de Estabilidade Financeira. Brasília, DF: Banco Central do Brasil, 2017. Available at: <https:// www.bcb.gov.br/htms/estabilidade/2017_10/refPub.pdf>. Accessed on: Nov. 18, 2020.

BANCO CENTRAL DO BRASIL. Novo Acordo de Capitais - Basileia II. Brasília, DF: Banco Central do Brasil, 2019a. Available at: <https:// www.bb.com.br/portalbb/page51,136,3442,0,0,1,8.bb?codigoNoticia $=4813 \&$ codigoMenu=413\&codigoRet=4119\&bread =9_1_4>. Accessed on: Nov. 18, 2020.

BANCO CENTRAL DO BRASIL. Panorama do sistema nacional de crédito cooperativo. Brasília, DF: Banco Central do Brasil, 2019b. Available at: <https://www.bcb.gov.br/pre/microFinancas/coopcar/ pdf/panorama_de_cooperativas2017.pdf >. Accessed on: Nov. 18, 2020.

BANKER, R. D.; CHARNES, A.; COOPER, W. W. Some models for estimating technical and scale inefficiencies in DEA. Management Science, v. 30, n. 9, p. 1078-1092, 1984.

BARROS, E. S.; TENORIO JUNIOR, A. J. A. Aplicação do método Bootstrap na estimação de fronteiras não paramétricas: o caso dos fruticultores do vale do São Francisco. Fortaleza: Banco do Nordeste, 2020. Available at: <https://www.bnb.gov.br/documents/160445/214098/ aplicacao_do_metodo.pdf/4849e96f-e713-404a-b73f-4aa88b9e4cfd>. Accessed on: Nov. 18, 2020.

BASEL CAPITAL ACCORD. International Convergence of Capital Measurement and Capital Standards (July 1988, Updated to April 1998). Basileia: Bank for International Settlements, 1988. Available at: <http://www.bis.org/publ/bcbsc111.pdf>. Accessed on: Nov. 18, 2020.

BASEL II. International Convergence of Capital Measurement and Capital Standards: a revised framework, comprehensive version.
Basileia: Bank for International Settlements, 2006. Available at: <https://www.bis.org/publ/bcbs128.pdf>. Accessed on: Nov. 18, 2020.

BERGER, A. N.; DEYOUNG, R. Problem loans and cost efficiency in commercial banks. Journal of Banking \& Finance, v. 21, n. 6, p. 849870, 1997.

BITTENCOURT, W. R. et al. Rentabilidade em bancos múltiplos e cooperativas de crédito brasileiros. Revista de Administração Contemporânea, v. 21, n. esp., p. 22-40, 2017.

BRANCO, A. M. F. et al. Efficiency of the Brazilian Banking System in 2014: A DEA-SBM Analysis. Journal of Applied Finance and Banking, v. 7, n. 5, p. 29-47, 2017.

BRASIL. Resolução no 2682, de 21 de dezembro de 1999. Dispõe sobre critérios de classificação das operações de crédito e regras para constituição de provisão para créditos de liquidação duvidosa. Brasília, DF: Diário da União, 1999. Available at: <http://www.bcb. gov.br/pre/normativos/res/1999/pdf/res_2682_v2_L.pdf >. Accessed on: Nov. 18, 2020.

BRASIL. Resolução $n^{\circ} \mathbf{4} .557$, de 23 de fevereiro de 2017. Dispõe sobre a estrutura de gerenciamento de riscos e a estrutura de gerenciamento de capital. Brasília, DF: Diário da União, 2017. Available at: <http:// www.bcb.gov.br/pre/normativos/busca/downloadNormativo.asp? arquivo=/Lists/Normativos/Attachments/50344/Res_4557_v1_O.pdf>. Accessed on: Nov. 18, 2020.

BRESSAN, V. G. F.; LOPES, A. L. M.; MENEZES, M. R. Análise de eficiência das cooperativas de crédito brasileiras utilizando informações contábeis. In: CONGRESSO INTEGRADO DE CONTABILIDADE, 1., 2013, Juiz de Fora. Anais... Juiz de Fora: UFJF, 2013. Available at: <http://www.ufjf. br/congreconti/files/2013/11/A9.pdf>. Accessed on: Nov. 18, 2020.

CAMPILLO, A. M.; SANTOS, Y. F. What about the Social efficiency in credit cooperatives? evidence from Spain (2008-2014). Social Indicators Research, v. 131, n. 2, p. 607-6299, 2016.

CAMPILLO, A. M.; SANTOS, Y. F.; FERNÁNDEZ, M. D. P. F. Eficiencia técnica en las cooperativas de crédito españolas: una aproximación al impacto de la crisis. Revista Española de Financiación y Contabilidad, v. 46, n. 4, p. 484-506, 2017.

CARNEIRO, M.; SALGADO JUNIOR, P. A.; MACORIS, L. S. Avaliação da eficiência bancária por meio da abordagem de intermediação: uma análise comparativa de instituições financeiras brasileiras. Revista Eletrônica de Administração, v. 22, n. 3, 336-359, 2016.

CAVA, P. B. et al. Evaluation of Bank Efficiency in Brazil: A Dea Approach. Revista de Administração Mackenzie, v. 17, n. 4, p. 62-84, 2016.

CÁZARES, C. C.; SÁEZ, C. B.; MARCO, T. G. You can't manage right what you can't measure well: Technological innovation efficiency. Research Policy, v. 42, n. 6-7, p. 1239-1250, 2013.

CHAIBI, H.; FTITI, Z. Credit risk determinants: evidence from a crosscountry study. Research in International Business and Finance, v. 33, p. 1-16, Jan. 2015.

CHANG, T. C.; CHIU, Y. H. Affecting factors on risk-adjusted efficiency in Taiwan's banking industry. Contemporary Economic Policy, v. 24, n. 4, p. 634-648, 2006. 
CHARNES, A.; COOPER, W. W.; RHODES, E. Measuring the efficiency of decision makingunits. European Journal of Operational Research, v. 2, n. 6, p. 429-444, Nov. 1978.

CHO, M.; CHUNG, K. H. The effect of commercial banks' internal control weaknesses on loan loss reserves and provisions. Journal of Contemporary Accounting \& Economics, v. 12, n. 1, p. 61-72, 2016.

CORDEIRO, F. A. et al. Desempenho financeiro das cooperativas de crédito brasileiras e a recessão econômica de 2015 no Brasil. In: CONGRESSO USP INTERNATIONAL CONFERENCE IN ACCOUNTING, 2018, São Paulo. Anais... São Paulo: USP, 2018. Available at: <https:// congressousp.fipecafi.org/anais/Anais2018/ArtigosDownload/1023. pdf>. Accessed on: Nov. 18, 2020.

COSTA, D. R. M. Rating de cooperativas agropecuárias: uma contribuição metodológica. 2005. Master Thesis (Master Degree in Applied Economics) - Escola Superior de Agricultura Luiz de Queiroz, Universidade de São Paulo, Piracicaba, 2005. Available at: <http://www.sbicafe.ufv.br/bitstream/handle/123456789/11996/ Dissertacao_Davi\%20Rogerio\%20de\%20Moura\%20Costa.pdf? sequence =1\&isAllowed=y>. Accessed on: Nov. 18, 2020.

CREAR, S. Co-operative banks, credit unions and the financial crisis (Paper for the UN Expert Group Meeting on Co-operatives). New York: World Council of Credit Union, 2009. Available at: <https:// www.un.org/esa/socdev/egms/docs/2009/cooperatives/Crear.pdf>. Accessed on: Nov. 18, 2020.

CUCINELLI, D. et al. Credit Risk in European Banks: The Bright Side of the Internal Ratings Based Approach. Journal of Banking and finance, v. 9, n. 3, p. 213-229, 2018.

DANTAS, J. A. et al. Determinantes do grau de evidenciação de risco de crédito pelos bancos brasileiros. Revista Contabilidade \& Finanças, v. 21, n. 52, p. 1-27, 2010.

FARRELL, M. J. The measurement of productive efficiency. Journal of the Royal Statistical Society, v. 120, n. 3, p. 253-290, 1957.

FERREIRA, M. A. M. et al. Previsão de risco de crédito para definição do perfil de clientes de um banco de varejo. Revista de Negócios, v. 16, n. 2, p. 47-64, 2011.

FIORDELISI, F.; MARQUES-IBANEZ, D.; MOLYNEUX, P. Efficiency and risk in European banking. Journal of Banking \& Finance, v. 35, n. 5, p. 1315-1326, 2011.

FRANCISCO, J. R. D. S.; AMARAL, H. F.; BERTUCCI, L. A. Risco de crédito em cooperativas: uma análise com base no perfil do cooperado. Sociedade, Contabilidade e Gestão, v. 7, n. 2, p. 137149, 2012.

FREITAS, A. F. D.; AMARAL, I. D. C.; BRAGA, M. J. A influência dos riscos de liquidez e de crédito no processo de conversão das cooperativas de crédito rural em cooperativas de crédito de livre admissão: um estudo de caso. Revista de Contabilidade e Organizações, v. 2, n. 4, p. 126-147, 2008.

GISCHER, H.; JÜTTNER, D. J. Profitability and competition in banking markets: an aggregative cross country approach. Madeburgo: Otto von Guericke University Magdeburg, 2001. Available at: <https://pdfs.semanticscholar.org/043d/ f11a0bc1718fb4382b608dd930937704685b.pdf>. Accessed on: Nov. 18, 2020.
GLASS, J. C. et al. Cooperative bank efficiency in Japan: a parametric distance function analysis. The European Journal of Finance, v. 20, n. 3, p. 291-317, 2014

HACKBARTH, D.; MIAO, J.; MORELLEC, E. Capital structure, credit risk, and macroeconomic conditions. Journal of Financial Economics, v. 82, n. 3, p. 519-550, 2006.

HOFF, A. Second stage DEA: comparison of approaches for modelling the DEA score. European Journal of Operational Research, v. 181, n. 1, p. 425-435, 2007.

HOU, X.; WANG, Q.; ZHANG, Q. Market structure, risk taking, and the efficiency of Chinese commercial banks. Emerging Markets Review, v. 20, p. 75-88, Sept. 2014.

HUSCHER, P. F. Modelo de rating para avaliação de cooperativas de crédito. 2017. Master Thesis (Master Degree in Cooperative Management) - Pontifícia Universidade Católica do Paraná, Curitiba, 2017.

IMBIEROWICZ, B.; RAUCH, C. The relationship between liquidity risk and credit risk in banks. Journal of Banking \& Finance, v. 40, p. $242-$ 256, Mar. 2014.

JORION, P. Value at risk: a nova fonte de referência para a gestão do risco financeiro. 2. ed. São Paulo: Bolsa de Mercadorias e Futuros, 2003.

KAUPELYTÈ, D.; MCCARTHY, O. Risk management in Lithuanian and Irish credit unions: trends and impacts on credit union development. Journal of Rural Cooperation, v. 34, n. 2, p. 179-194, 2006.

KAR, S.; DEB, J. Efficiency determinants of microfinance institutions in India: an indicative DEA approach. Abhigyan, v. 36, n. 2, p. 1-11, 2018.

KRAKAH, A. K.; AMEYAW, A. The determinants of bank's profitability in Ghana: the case of Merchant Bank Ghana Limited (MBG) and Ghana Commercial Bank (GCB). 2010. Master Thesis (Master Degree in Business Administration) - School of Management, Blekinge Institute of Technology, Karlshamn, 2010.

LIMA, F. G. et al. Os determinantes dos ratings de crédito dos bancos brasileiros. Revista de Administração Contemporânea, v. 22, n. 2, p. 178-200, 2018.

MARCUCCI, J.; QUAGLIARIELLO, M. Asymmetric effects of the business cycle on bank credit risk. Journal of Banking \& Finance, v. 33, n. 9, p. 1624-1635, 2009.

MELO, E. S.; LIMA, J. E. Análise do risco de liquidez em cooperativas de crédito de economia solidária: o caso do sistema Cresol. Gestão Contemporânea, v. 17, p. 104-128, 2015.

MOTTA, A. Na contramão dos bancos, cooperativas de crédito abrem agências. Exame, São Paulo, 02 fev. 2018. Available at: <https:// exame.com/seu-dinheiro/na-contramao-dos-bancos-cooperativasde-credito-abrem-agencias/>. Accessed on: Nov. 18, 2020.

MUSAU, S.; MUATHE, S.; MWANGI, L. Financial inclusion, bank competitiveness and credit risk of commercial banks in Kenya. International Journal of Financial Research, v. 9, n. 1, p. 203-218, 2018.

PASTOR, J. M.; SERRANO, L. Efficiency, endogenous and exogenous credit risk in the banking systems of the Euro area. Applied Financial Economics, v. 15, n. 9, p. 631-649, 2005.

PEÑA, C. R. Um modelo de avaliaçăo da eficiência da administraçăo pública através do método análise envoltória de dados (DEA). Revista de Administração Contemporânea, v. 12, n. 1, p. 83-106, 2008. 
PEREIRA, J. M. Gestão do risco operacional: uma avaliação do novo Acordo de Capitais-Basileia II. Revista Contemporânea de Contabilidade, v. 6, n. 3, p. 103-124, 2006.

PODPIERA, J.; WEILL, L. Bad luck or bad management? Emerging banking market experience. Journal of Financial Stability, v. 4, n. 2, p. 135-148, 2008.

SAEED, M.; IZZELDIN, M. Examining the relationship between default risk and efficiency in Islamic and conventional banks. Journal of Economic Behavior \& Organization, v. 132, n. 12.2016, p. 127-154, 2014.

SALAS, V.; SAURINA, J. Credit risk in two institutional regimes: Spanish commercial and savings banks. Journal of Financial Services Research, v. 22, n. 3, p. 203-224, 2002.

SANG, M. N. Income diversification and bank efficiency in Vietnam. Journal of Economics and Development, v. 19, n. 3, p. 52-67, 2017.

SARMIENTO, M.; GALÁN, J. E. The influence of risk-taking on bank efficiency: evidence from Colombia. Emerging Markets Review, v. 32, p. 52-73, Sept. 2017.

SATHYE, M. The impact of internet banking on performance and risk profile: evidence from Australian credit unions. Journal of Banking Regulation, v. 6, n. 2, p. 163-174, 2005.

SILVA, R. A. Performance financeira da carteira na avaliação de modelos de análise e concessão de crédito: uma abordagem baseada em aprendizagem estatística. 2014. Doctoral Dissertation (Doctor Degree in Business Administration) - Faculdade de Economia, Administração e Contabilidade de Ribeirão Preto, University of São Paulo, Ribeirão Preto, 2014. Available at: <http://www.teses.usp. br/teses/disponiveis/96/96132/tde-04112014-165830/en.php>.

Accessed on: Nov. 18, 2020.

SOUZA, U. R. D.; BRAGA, M. J.; FERREIRA, M. A. M. Fatores associados à eficiência técnica e de escala das cooperativas agropecuárias paranaenses. Revista de Economia e Sociologia Rural, v. 49, n. 3, p. 573-597, 2011.

STAUB, R. B.; SOUZA, G. D. S.; TABAK, B. M. Evolution of bank efficiency in Brazil: a DEA approach. European Journal of Operational Research, v. 202 , n. 1 , p. 204-213, 2010.
STIGLITZ, J. E. The role of the state in financial markets. The World Bank Economic Review, v. 7, n. 1, p. 19-52, 1993.

STUCHI, L. G. Quantificação de risco de crédito: uma aplicação do modelo CreditRisk + para financiamento de atividades rurais e agroindustriais. 2004. Master Thesis (Master Degree in Applied Economics) - Escola Superior de Agricultura Luiz de Queiroz, Universidade de São Paulo, Piracicaba, 2004. Available at: <http:// www.teses.usp.br/teses/disponiveis/11/11132/tde-13072004151006/en.php>. Accessed on: Nov. 18, 2020.

SUN, L.; SUN, X.; RABARISON, M. K. Performance efficiency evaluation of US Credit Unions around the 2009 global recession: a data envelopment analysis approach. The Journal of Business Inquiry, v. 18, n. 2, p. 120-142, 2018.

TABAK, B. M.; CRAVEIRO, G. L.; CAJUEIRO, D. O. Eficiência bancária e inadimplência: testes de causalidade (Trabalho para discussão do Bacen n. 220). Brasília, DF: Banco do Brasil, 2010. Available at: <https://www.bcb.gov.br/pec/wps/port/TD220.pdf>. Accessed on: Nov. 18, 2020.

TAN, Y.; ANCHOR, J. The impacts of risk-taking behaviour and competition on technical efficiency: evidence from the Chinese banking industry. Research in International Business and Finance, v. 41, p. 90-104, Oct. 2017.

TAN, Y.; FLOROS, C. Risk, competition and efficiency in banking: evidence from China. Global Finance Journal, v. 35, p. 223-236, Feb. 2018.

TOLEDO, J. R.; KROENKE, A.; SOTHE, A. Impacto da crise do subprime na provisão do risco de crédito dos maiores bancos nacionais. Revista Brasileira de Gestão de Negócios, v. 11, n. 32, p. 248-259, 2009.

TURNER, H.; WINDLE, R.; DRESNER, M. North American containerport productivity: 1984-1997. Transportation Research Part E - Logistics and Transportation Review, v. 40, n. 4, p. 339-356, 1997.

VIEIRA, L. K. Diversificação de receitas e o desempenho das cooperativas de crédito brasileiras. 2016. Master Thesis (Master Degree in Accounting Sciences) - Universidade Federal de Minas Gerais, Belo Horizonte, 2016. Available at: <http://www.bibliotecadigital.ufmg.br/ dspace/handle/1843/BUOS-BADJMR>. Accessed on: Nov. 18, 2020.

WORTHINGTON, A. C. Measuring technical efficiency in Australian credit unions. The Manchester School, v. 67, n. 2, p. 231-248, 1999. 
Lua Syrma Zaniah Santos

ORCID: https://orcid.org/0000-0003-3829-9530

Master in Controllership and Accounting from the Federal University of Minas Gerais (UFMG), Belo Horizonte-MG, Brazil. E-mail: luasyrma@gmail.com

ORCID: https://orcid.org/0000-0001-6340-9717

D.Sc. in Applied Economics and Associate Professor at the Faculty of Economic Sciences from the Federal University of Minas Gerais (UFMG), Belo Horizonte-MG, Brazil.E-mail: valeriafully@ufmg.br

Vilmar Rodrigues Moreira

ORCID: https://orcid.org/0000-0003-1796-6752

D.Sc. in Business Administration and Professor at the School of Business at the Pontifical Catholic University of Paraná (PUCPR), Curitiba - PR, Brazil. E-mail: vilmar.moreira@pucpr.br

Romeu Eugênio de Lima

ORCID: https://orcid.org/0000-0003-0464-1115

D.Sc. in Administration from the Federal University of Minas Gerais (UFMG), Belo Horizonte - MG, Brazil. E-mail: romeu.lima@bcb.gov.br 